\title{
РАЗМАТРАЊА О СМИСЛУ ФИЛОЛОГИЈЕ У СВЕТЛУ ДУХОВНИХ НАУКА
}

\section{Сажетак}

Насупрот савременом распаду филологије на њене бројне засебне дисциплине, овај рад указује на јединствени смисао ове науке који почива на романтичарским темељима Бековог, а касније и Дилтајевог схватања њене улоге у духовној историји. При томе се схватање филологије код ове двојице великих мислилаца у овом раду снажно супротставља данашњој позицији ове науке. Овај рад се може посматрати као наставак тезе Миодрага Ломе, који је у тексту „Филологија и њене дисциплине“ испитивао могућности повезивања филолошких дисциплина управо на темељима филологије који су постављени у 19. веку.

Кључне речи: филологија, духовно, историја, разумевање, језик, спознање, хуманистичко.

Вероватно најчешћа асоцијација на „филологију“ у данашње време је проучавање светских језика и књижевности. У Речнику књижевних термина „филологија“ је дефинисана на два начина: 1) као целокупна област проучавања језика, усмене и писане књижевности и уопште духовне културе једног народа, са изразитом историјском оријентацијом, и 2) као тумачење писаних текстова у књижевне и културноисторијске сврхе (RKT: 206) ${ }^{1}$.

\footnotetext{
* Филолошки факултет, Студентски трг 3, 11000 Београд vedrancv@gmail.com

1 Сва скраћена навођења у овом чланку дата су у списку коришћене литературе на крају овог рада.
} 
У време заснивања националних филологија, почетком 19. века, држао је немачки класични филолог Аугуст Бек предавања о „Енциклопедији филологије“ (1809-1865) на Хајделбершком, а од 1811. године и на новооснованом Берлинском универзитету. Он је дефинисао филологију као појмовно разумевање и објашњење, односно „спознање онога што је продуковао људски дух, тј. онога што је већ спознато“ (Boeckh 1877: 9-10). Очевидно је да се примарно значење филологије, оно које се налази у Речнику књижевних термина, умногоме ослања на Беково схватање ове науке. Време када је Бек држао своја филолошка предавања јесте период романтичарског заснивања националних филологија. Најснажнији подстицај за овај научни пробој филологије дао је Хердер, који је у својој студији О пореклу језика из 1770. године најпре установио идентитет говорења и мишљења, идеји на којој почива став овог немачког критичара да универзални историјски контекст - превасходно онај језички - чине различити национални језици (Лома 2013: 376; Хердер 2012)2. Тако је Хердер већ у својим младалачким данима филологији дао фундаментални значај, који ће Аугуст Бек искористити за сопствено схватање и дефинисање ове науке. Као најопштије средство људског спознања одредио је Бек језик, који је за њега „чист израз сваког спознавања, а не само оног разумског“ (Boeckh 1877: 12; Лома 2013: 376). Овом дефиницијом Бек је проширио подручје филологије на „свеукупну људску делатност која је историјски изражена“ (Лома 2013: 376).

Романтичарско схватање филологије Аугуста Бека дијаметрално је супротно данашњој позицији ове науке, која је распарчана на своје засебне и међусобно неповезане дисциплине. Стога се морамо запитати да ли појединачне филолошке дисциплине „као научне могу постојати без свести о филолошкој науци која их све обухвата и осмишљава?" (Лома 2014: 38) Управо у смислу негативног одговора на ово питање писао је Бек у својој Енциклопедији, где је и дефинисао филологију. Он је нагласио да ова, као и било која друга наука, мора својим појмом обухватити све оне делове који су са њом у односу. Ти делови морају проистицати из заједничког смисла који је садржан у

2 Детаљније о Хердеровом доприносу научном заснивању филологије можете прочитати у чланку Миодрага Ломе: „Хердерово схватање порекла језика и заснивање филологије", Зборник матице српске за књижевност и језик, 61/2 (2013): 375-402. 
општем појму филологије који их обухвата. Слично је, каже Бек, и са филозофијом: „појам филозофије је општи; од тих [њених] дисциплина свака је појединачно филозофија само у једном посебном правцу ${ }^{3}$, а ови особени правци морају происходити из самог [општег] појма“ (Boeckh 1877: 3). Дакле, филологију морамо схватити као

„науку која својим јединственим и вишим појмом обухвата појмове својих појединачних дисциплина и организује их у једну методичну и систематичну целину, тако што се кроз њих делимично остварује у модификацијама сходним посебностима сваке од тих дисциплина, односно њихових појмова“ (Лома 2014: 38).

Тако се филологија конституише као универзална духовна и историјска наука која испитује сва испољавања људске духовности (исто: 39). Конкретно, предмет ове науке је усмена и писмена заоставштина језичких трагова људских духовних потенција. Сваки од тих трагова носи у себи одређени историјски и културолошки код, који је специфичан носилац вредности за одређено историјско раздобље и идентификује конкретне људске духовне могућности у одређеном временском периоду. Стога предмет филолошке науке, насупрот ономе природних наука, не може никада застарити, нити може бити превазиђен нечим новијим и напреднијим (Лома 2014).

Вероватно је Вилхелм Дилтај (1833-1911) имао у виду ово својство филологије када је у Берлину 1883. године писао свој Увод у духовне науке, где је говорио о разлици између духовних и природних наука. Дилтајева замисао била је да разреши кризу историјске школе која је, према његовом уверењу, била осакаћена упливом позитивистичког, природно-научног утицаја (Diltaj 1980: 45; Dilthey 1883: XVI). Његова идеја нашла је упориште „у унутрашњем искуству“, односно „у чињеницама свести“ (Diltaj 1980: 45). Оне су за Дилтаја емпиријске природе, али своје значење и смисао добијају тек након рационалне обраде. Стога он закључује да се субјективна стварност образује на основу искуства које има свој „изворни склоп“ (ursprunglischen Zusammenhang) и специфично значење у условима наше свести (Diltaj 1980: 45-46; Dilthey 1883: XVI). Иако је дотична стварност субјективне природе, овај немачки научник је сматрао да је задатак духовних нау-

3 Бек мисли на обичаје, право, религију, логику, а свака од њих садржи учење о обичајима, праву, филозофији религије и природној филозофији. 
ка да сазнање које се из њих добија доведе до објективне вредности. Међутим, Дилтајева епистемолошка схема не ослања се само на филозофске поставке осамнаестовековног рационализма, где за њега протиче само „разређени сок ума као пуке делатности мишљења“ (Diltaj 1980: 46). Овај берлински професор се човеком бавио у његовој егзистенцијалној целини, историјски и психолошки, те га је у синтетичком јединству ове две димензије стварности одредио као средиште духовних наука и њихов сазнајни субјекат.

Дилтајева филозофска уверења оформила су се у време када је Европа проживљавала турбулентан духовни период. Идеја напретка и просперитет науке у 18. веку били су кључни чиниоци, услед којих је хришћански мит постепено замењивала нова парадигма филозофског промишљања. Реч је о надасве рационалном схватању човека као првенствено бића разума (ens rationis). Дилтај није прихватао овај прекомерни рационализам. Корени његове филозофије налазе се у емпиричкој филозофији првенствено Велике Британије и у трансценденталној филозофији после-Кантовске Немачке (Hodges 1944: 2-3). Својства која је он преузео из ових осамнаестовековних филозофских струја тичу се психологије и емпиричког приступа анализи чињеница. Дилтајева генерација је дочекала слом романтичарског јединства филозофије и уметности. Материјализам и позитивизам су све више преузимали примат у филозофији, а јавила се потреба и за повратак Кантовој филозофији, то јест њеним трансценденталнопозитивистичким начелима из прве Критике. Повратак Канту прижељкивао је и сам Дилтај, али не на овај начин. Он је желео повратак целокупном Канту, који се није бавио само научним постулатима, већ је указао на моралну, естетску и религиозну свест која је у позадини метафизичког мишљења. Задатак филозофије, како је то видео Дилтај, био је да утврди епистемолошку и логичку основу историјске науке и да ту основу угради у кантовску структуру мишљења (Hodges 1944: 5-7).

Оно што је кључно за филологију у Дилтајевој интелектуалној оставштини потиче од утицаја који је на овог филозофа извршио Фридрих Шлајермахер. Његова анализа религијске свести, а понајвише његова херменеутика, теме су које су имале најснажнији одјек у Дилтајевој филозофији (Hodges 1944: 7). Већ је поменуто Дилтајево уверење да духовне науке морају подићи чињенице свести 
до објективности, коју је овај научник сматрао кључним својством филолошке и историјске науке.

У кратком одељку Увода у духовне науке, који носи наслов „Настанак херменеутике“, Дилтај је истакао да „наше деловање свугде претпоставља разумевање других личности“ (Diltaj 1980: 94). Дакле, примарни циљ филолошке науке је да то хуманистичко разумевање доведе до објективности, што би јој дало научни статус. Да би се постигла та жељена објективност нужно је да, како то види Дилтај, филологија у својој основи задржи поступке разумевања и тумачења. Овим ставом немачки филозоф је одредио херменеутику као методолошки поступак од кога непосредно зависи научни статус филологије (Diltaj 1980: 94-95). Само разумевање Дилтај је дефинисао као „поступак, којим из знакова који су нам споља дати сазнајемо оно унутрашње“ (Diltaj 1980: 95), док је тумачење за њега вештина „разумевања трајно фиксираних испољавања живота" (Diltaj 1980: 96). Таква испољавања живота су за овог научника неми споменици културе, као што су скулптуре и слике. Предмет од значаја за филологију је, у овом смислу, литература. Према томе, Дилтај закључује да „унутрашњи живот човека једино у језику налази свој потпуни, исцрпни и објективно разумљиви израз. Због тога тумачење или интерпретација у писму садржаних остатака људског бивства представља средиште вештине разумевања" (Diltај 1980: 96-97). Према томе, писмена заоставштина (нарочито она значајних личности) је најдрагоценији предмет филолошке науке. Она пружа непосредни увид у душевни идентитет великих личности и у историјске околности које су деловале на те идентитете, константно их обликујући. Стога је Дилтај делу неког песника, проналазача, религиозног генија или филозофа, придао општеважећи објективни значај, који не може бити релативизован неким другим аналитичким и утилитарним методама стицања сазнања, која филологији нису примерена. Он тврди да је такво једно дело „у овом људском друштву пуном лажи [...] увек истинито.“ Оно „омогућава само за себе потпуну и објективну интерпретацију“, а такође „баца светло на друге уметничке споменике једног времена и на историјска делања савременика“ (Diltaj 1980: 97). Дилтај сматра да су из потреба разумевања тих дела и њихових твораца, филолози у вештину интерпретације постепено 
уводили правила. Из настојања да се она образложе и разумеју „настала је херменеутичка наука“, која је „учење о вештини тумачења писаних споменика" (Diltaj 1980: 97). Тако за Дилтаја две врсте анализе - оне унутрашњег искуства и разумевања - чине основу целокупних духовних наука, пружајући им „доказ о могућностима и границама општеважећег сазнања у њима“ (Diltaj 1980: 97).

У нацрту за Изградњу историјског света у духовним наукама, Дилтај је резимирао али и обогатио своја разматрања о херменеутици и тумачењу из Увода у духовне науке. За разлику од већине осамнаестовековних немачких мислилаца, Дилтај је имао пуно поверење у могућности језика да „потпуно и исцрпно“ изрази човеков духовни живот (Diltaj 1980а: 278). Управо ово језичко својство - да веродостојно изрази човекова духовна искуства - темељ је објективном сазнању коме је тежио овај немачки научник. У Изградњи историјског света, Дилтај за тумачење везује две кључне духовно-сазнајне компоненте: накнадно доживљавање и критику. Накнадно доживљавање (Nacherleben) објашњава Дилтај као процес предочавања неке средине и неког спољашњег стања, који се дешава у нашој свести (Diltaj 1980а: 276). Реч је о процесу који омогућава разумевање других личности (Hodges 1944: 160), што је, према Дилтају, од суштинске важности за духовне науке у целини. Критику је немачки научник замислио као помоћну херменеутичку дисциплину која служи за пречишћавање текстова. Дакле, Дилтај је херменеутици, као чисто филолошкој дисциплини, одредио фундаментални значај у склопу духовних наука. Међутим, чињеница да се овде ради о филолошкој дисциплини није код овог научника ограничила њену примену на писмену и усмену традицију, већ је Дилтај доводи у везу и са разумевањем било каквих животних манифестација. Премда је Дилтај више пута наглашавао важност објективног сазнања у филолошкој науци, он је поменуо и немогућности да се целокупан процес разумевања репрезентује било каквим обрасцима логичких радњи. Разлог за ово ограничење он приписује ирационалној компоненти која је природна процесу разумевања: „У свем разумевању има нечег ирационалног, а такав је и сам живот" (Diltaj 1980a: 276).

Дилтај је у више наврата истакао велики допринос Аугуста Бека филологији (Diltaj 1980: 106, 111-112, 116, 137; Diltaj 1980a: 278, 279). Бекову дефиницију филологије као „сазнања онога што је људски дух 
произвео, тј. оног сазнатог“, кориговао је Дилтај увидом да произведено и сазнато не могу бити идентични (Diltaj 1980: 116). Он сматра да у „производњи заједно делују све духовне снаге“, али да је у произведеном садржано нешто више од сазнања (Diltaj 1980: 116). Тиме је овај немачки научник указао на идеју да стваралац није нужно оптерећен стицањем сазнања приликом свог креативног чина, док је објективно сазнање главни циљ тумача. Стога је филологија за Дилтаја, у најобухватнијем смислу, „склоп делатности кроз које се оно историјско доводи до разумевања“ (Diltaj 1980: 116). Дилтај је напоменуо да објективно сазнање зависи од личне генијалности сваког појединачног филолога. Тим увидом он је посредно истакао субјективну компоненту сваког херменеутичког чина при анализи текстуалних садржаја, која пак настоји да буде објективна. Будући да се „објективно“ дефинише као независно од субјекта (РCJ: 834), а идеал објективности као сасвим недостижан у духовним наукама (РФП: 395), отвара се простор за критику ове наизглед нерешиве противречности у погледу научног статуса филологије. Дилтај је овај проблем покушао да превазиђе потпуним прихватањем „субјективног“, односно указивањем на оно људско и животно, што је у средишту свих духовних и материјалних збивања. Стога се у Дилтајевом смислу „објективно“ никако не односи на дијапазон природнонаучних сазнања, која су ограничена на материјални свет, већ на сазнања у чијем средишту су човек и његов живот, схваћени у њиховој свеобухватној духовности. Према томе, Дилтај закључује да само у духовном свету, „који се стваралачки креће у нама, [...], живот има своју вредност, своју сврху и своје значење“ (Diltaj 1980a: 150).

Што се тиче Аугуста Бека, он је разумевање одредио као појмовно спознање онога што је већ спознато (Boeckh 1877: 52). Миодраг Лома је запазио да је овом дефиницијом Бек истакао „метод специфичног филолошког сазнања чији је предмет одредив као свеобухватно језички“ (Лома 2014: 41). Затим је Бек истакао да из филологије проистичу формални и материјални део, који је у потпуности исцрпљују. Формални део подразумева приказ разумевања, као својственог акта филологије, док се материјални део односи на „укупну грађу коју је ова наука уобличила“ (Boeckh 1877: 52-53; Лома 2014: 41). Формални део, то јест разумевање, Бек дели на „апсолутно“, 
којим се бави херменеутика, и „релативно“, којим се бави критика. Херменеутика је методски примарна филолошка дисциплина која омогућава разумевање туђих израза и мисли, односно реконструкцију тог језичког процеса као најопштијег органона саопштења (Boeckh 1877: 80-81; Лома 2014: 41). Критика је методски секундарна филолошка дисциплина. Она се бави просуђивањем релација одређеног текста са датим контекстима (Boeckh 1877: 170; Лома 2014: 44). Исказано појмовима модерне науке о књижевности, функција херменеутике коју је замислио Бек би, у извесном смислу, одговарала „унутрашњем приступу" књижевном делу, док би се критика бавила његовим „спољашњим“ приступом (Лома 2014: 42).

Према Беку и Дилтају, сваки појединачни филолог у свом приступу једном делу, мора узети у обзир херменеутику и критику, то јест унутрашње и спољашње посматрање тог дела. Херменеутички приступ било ком делу мора, према Бековом схватању, „водити рачуна о неопходним смисаоним контекстима по чијим условима текст тек постаје разумљив, али превасходно пазећи на особено конституисање властитог смисла самог текста на основу његових контекстуалних смисаодавних условљавања“ (Лома 2014: 42). Сврха херменеутике за Бека је „разумети сам премет о коме се ради у његовој сопственој природи“ (Boeckh 1877: 77).

Највећи Беков допринос филологији јесте у томе што ју је утемељио као обухватну историјску науке. Према њему, филологија увек претпоставља једно унапред дато знање, које она треба поново да спозна. Стога је историја сваке науке филолошка, те је филологија „универзална и фундаментална“, односно „хуманистичка наука“ (Boeckh 1877: 10-11). Као таква, „она не може бити прагматична“ јер је њена педагошка сврха „што целовитије образовање људскости, а не неки циљ практичног живота“ (Лома 2014: 47). Управо је на Бековом схватању филологије као духовноисторијске науке, Дилтај утврдио своје методолошко полазиште за раздвајање духовних од природних наука (Лома 2014: 46). Према томе, требало би да савремена филолошка заједница ради на томе да се филологији, као свеобухватној духовној науци, поврати њен изворни аристотеловски смисао енциклопедијског образовања људског рода. Само при сталном осврту на њену обухватну енциклопедијскусврху и крајњи смисао, можемо филологијузаштитити 
од савременог распада на небројене појединачне дисциплине које замагљују овај изворни и прави научни смисао филологије. Тај смисао филолошка заједница мора очувати учесталим враћањем историјским зачецима филолошке науке, онако како су она утемељена код великих филолога попут Дилтаја и Бека.

\section{Извори и цитирана литература}

Boeckh, August. Encyklopädie und Methodologie der Philologischen Wissenschaften. Lepzig: Druck und Verlag von B. G. Teubner, 1877. PDF.

Diltaj, Vilhelm. Zasnivanje duhovnih nauka. Prevod: Zoran Đinđić i Jelena Imširović. Beograd: Prosveta, 1980. Štampano.

Diltaj, Vilhelm. Izgradnja istorijskog sveta u duhovnim naukama. Prevod: Dušica Guteša. Beograd: Beogradski izdavačko-grafički zavod, 1980a. Štampano.

Hodges, H. A. Wilhelm Dilthey: An Introduction. London: Butler and Tanner Ltd., 1944. PDF. RKT: Rečnik književnih termina. Glavni i odgovorni urednik: prof. dr Dragiša Živković. Beograd: Institut za književnost i umetnost, Nolit, 1986. Štampano.

Миодраг, Лома. „Филологија ињене дисциплине“. Култура, цивилизација, филологија (том VI). Јулијана Вучо (гл. уред.), Љиљана Марковић (ур.) и Александра Вранеш (ур.), Београд: Филолошки факултет, стр. 37-53. Штампано.

Миодраг, Лома: „Хердерово схватање порекла језика и заснивање филологије“, Зборник Матице српске за књижевност и језик, књига 61, свеска 2, Нови Сад: Матица српска, стр. 375-402. Штампано.

PCJ: Речник српскога језика. Редиговао и уредио: Мирослав Николић. Нови Сад: Матица српска, 2011. Штампано.

РФП: Речник филозофских појмова. Ур. српског издања: Тиодор Росић. [Наслов оригинала: Wörterbuch der philosophischen Begriffe, begründet von Friedrich Kirchner und Carl Michaëlis, fortgesetzt von Johannes Hoffmeister, vollständig neu hrsg. von Arnim Regenbogen und Uwe Meyer. Felix Meiner Verlag, Hamburg 1998] Превод: Александар Гордић. Београд: БИГЗ, 2004. Штампано. 


\section{Vedran Cvijanovć}

\section{REFLECTIONS UPON THE MEANING OF PHILOLOGY IN LIGHT OF THE GEISTESWISSENSCHAFTEN}

\section{Summary}

Contrary to contemporary dissolution of philology to its specific disciplines, this paper points to a unique meaning of this science which rests on romantic foundations of Boeckh's and Dilthey's understanding of its role in Geistesgeschichte. In addition, this paper contrasts these two eminent thinkers' understanding of philology with the place of this science in today's world. Therefore, one could consider this work as continuation of Miodrag Loma's thesis, who in his text "Philology and its Disciplines" examined the possibility of bringing together philological disciplines on the basis of philology's foundations established in the $19^{\text {th }}$ century. In view of Boeckh and Dilthey's understanding of philology, its methodology and aims, contemporary philological community should seek to overcome the current dissolution of philology by returning to its scientific origins, as established by leading philologists such as Boeckh and Dilthey. humanistic.

Key words: philology, spiritual, history, understanding, language, knowing, 